S stenotopical for climatic and edaphically ecological factors habitat. Ecological features of this species are presented by different tolerance ranges of scoring. These features show adaptation level of sedge bohemica to its occupied ecological nicheand can partially describe its rarity in Ukraine.

Key words: ecological scale, synfytoindikation, rarely species, Carex L., Ukraine.

Стаття надійшла до редколегії 12.09.2016 р.

УДК $574.5(477.7)$

Ірина Мазур

\title{
Екологічна оцінка фіторізноманіття плавневих біотопів степових річок межиріччя Тилігулу-Південного Бугу
}

Проведено екологічну оцінку фіторізноманіття плавневих бітопів степових річок межиріччя Тилігулу-Південного Бугу з використанням аналітично-статистичних методів, а саме інформаційно-статистичних індексів флористичного багатства - індексу різноманіття Шенона (1949) та домінантності фітоугруповань (за індексами Сімпсона (1949) та Бергера-Паркера (1970)). Аналітичний аналіз засвідчив, що найбільше різноманіття біоти характерне для прибережно-водної рослинності плавнів. Флористично «збідненими» $\epsilon$ ценози остепнених та засолених луків із нерівномірним розподілом рясності видів відповідних угруповань або високим ступенем домінантності.

Ключові слова: екологічна оцінка, фіторізноманіття, плавневі біотопи, степові річки, межиріччя ТилігулПівденний Буг.

Постановка наукової проблеми та їі значення. Видове багатство - одна 3 найбільш важливих характеристик будь-яких біотичних угруповань, що відображає їхню екологічну специфіку, ієрархічну структуру та рівень різноманіття (відносний). Усі ці параметри пов'язані з особливостями конкретного біоценозу, фазовим станом екосистеми (розвиток, стабільність, клімакс, сукцесія), рівнем ії деструкції й трансформації [12].

Плавні рівнинних річок степової зони Тилігуло-Бузького межиріччя відрізняються низкою екологогідрологічних умов, відповідно до яких відбувалися формування та адаптаційні перетворення локальнобіотичних комплексів [9; 11]. Останні за ключовими біогеографічними ознаками, віком, генезисом і видовим складом тяжіють до Дунай-Дністровської й Дніпрово-Бузьких дельтово-плавневих масивів [3]. Водночас украй нестабільний гідрологічний режим (i сезонний, і багаторічний) малих річок зумовив виникнення у їхніх долинах специфічних ландшафтно-екологічних формацій інтразонального типу, рослинність яких, завдяки біотопічній мозаїчності заплав, набула змішаного (за типовим біотопом) характеру й значного різноманіття. При цьому сучасні плавневі фітокомплекси в зоні причорноморських степів $€$ інтразональними побудовами реліктового типу, які, на відміну від трансформованих первинно-степових і напівпустельних прибережних фітокомплексів, зберегли первинне видове ядро й загальний характер своїх угруповань. Останні досить детально описано, вивчено та опубліковано на прикладі дельтових і заплавних плавнів Дунаю, Дністра, Дніпра, Дону, Кубані [3], але специфічна рослинність плавнів малих річок із нестабільним гідрологічним режимом лишається малодослідженою. У флористичному відношенні їх зазвичай сприймають у якості спрощених і збіднених у видовому відношенні варіантів, які утворились унаслідок деградації типових плавнів [3]. Подібний підхід апріорі відкидає можливість автономного існування в долинах малих річок складних, структурованих на різних рівнях і багатих видами повноцінних фітокомплексів, відмінних від типових рослинних комплексів дельтових плавнів. На жаль, локальність і багатотиповість плавнів степових річок, які постійно перебувають під потужним антропогенним тиском на фоні аридизації клімату регіону, спричиняе загрозу остаточного зникнення цих унікальних за рівнем біорізноманіття природних комплексів раніше, ніж вони будуть вивчені.

Аналіз досліджень цієї проблеми. Степові річки, у тому числі річки Тилігуло-Бузького межиріччя, слугували об'єктами окремих описів та різнопланових досліджень практично з початку XIX ст. Завдяки їм

(C) Мазур I., 2016 
зараз для всієї зони Північно-Західного Причорномор'я існують об'ємні ретроспективні й сучасні матеріали ботанічного та геоботанічного плану. Особливо «багаті» напрацювання щодо нижньої частини течії Південного Бугу, а також дельтових зон Дунаю-Дністра й Дніпра, які представлені в роботах Й. К. Пачоського (1915, 1917), Д. В. Дубини (1989, 2000-2015), Ю. Р. Шеляг-Сосонко (1989, 2000), Н. П. Гальченко (2004) та гідробіолога Г. О. Карпової (1994). Накопичено також значні обсяги гідрологічних досліджень річок регіону, у тому числі водотоків Тилігуло-Бузького межиріччя, вивченням яких займалися представники Одеської геолого-гідрографічної школи під керівництвом Н. С. Лободи $(2012,2014)$ та Е. Г. Конікова (2013). При цьому системні, суто екологічної спрямованості дані щодо плавневої рослинності малих річок усього Півдня України загалом до сьогодні практично відсутні.

Мета дослідження - екологічна оцінка фіторізноманіття плавнів річкових долин Тилігуло-Бузького межиріччя, наявних у сучасних еколого-гідрологічних умовах.

Матеріали та методи. Базисним матеріалом для підготовки статті слугували результати власних еколого-гідрологічних, біокліматичних і флористичних обстежень плавнів річок Кодими, Тилігулу, Сасика, Березані, Чичиклії, Чертали, Бакшали та правобережжя пониззя Південного Бугу. Указані дослідження виконано впродовж 2012-2016 рр., у сезонно різні фази існування річкових водотоків та їх плавневої рослинності [1-9]. Останні проводили експедиційно, а також на модельних ділянках, перелік яких охоплював неоднорідні в екологічному плані місцевості з відповідними біотичними комплексами. Отримані результати польових обстежень, ботанічних зборів, гідрологічного контролю, а також лабораторних експертиз проб грунту й річкової води постійно піддавали порівняльним та аналітичним дослідженням із використанням ретроспективних даних і матеріалів щодо екологічних умов та специфіки рослинності плавнів інших річок регіону.

Із метою отримання первинних аналітичних узагальнень щодо якісного й кількісного складу плавневої рослинності малих річок та їі залежності від певних екологічних факторів середовища, а також для диференціації від характеристик плавневих фітоугруповань Дунаю, Дністра й Дніпра використано спеціальні аналітично-статистичні методи, рекомендовані для подібних завдань [10; 13-15]. Серед останніх - інформаційно-статистичні індекси, які надали можливість установити кількісні показники плавневої рослинності, виявити загальні та локальні особливості фонових й едифікаторних видів, простежити залежності останніх від властивостей і складу грунту, рівня зволоженості тощо.

Значна різнотиповість і чисельність рослинних угруповань плавнів спонукали до використання одночасно декількох індексів різноманіття, що дало змогу фіксувати флористичне багатство (індекс Шенона), домінантність і міру вирівняння видової структури цих угруповань (індекс Сімпсона та БергераПаркера) [13-15].

При визначенні типології фітоугруповань та їх реальних меж у просторі використовували поняття інвентаризаційного різноманіття за Уїттекером (1972), за яким загальне фіторізноманіття плавнів поділяли на чотири рівні [16]. Перший - точкове різноманіття, під яким сприймали рослині угруповання в межах однорідного екотопу (очеретяні, рогозові, комишеві, лепешеняково-бульбокомишеві тощо). Другий рівень альфа-різноманіття, яке поєднує угруповання в межах біотопічно окремих місцезростань (водно-болотного, лучно-болотного або лучного типу). Третій рівень - гамма-різноманіття, для якого характерний розгляд угруповань у межах ландшафтної типології (плавневі, лучні, степові, лісові тощо). Четвертий рівень - епсілонрізноманіття - передбачає розгляд рослинних угруповань у межах регіону (Північно-Західне Причорномор'я).

Для отримання всіх вибірок однакового розміру, використовували рясність видів у межах точкових рослинних угруповань на однорідних екотопах.

Виклад основного матеріалу й обгрунтування отриманих результатів дослідження. Гідрологічний стан водотоку - ключовий фактор впливу на стан плавневих біоценозів [3; 9; 11]. Генезис і сучасний стан степових водотоків Свразії у функціональному плані чітко визначені реалізацією сезонного дренування місцевості. Відповідно, гідрологічний режим річок Тилігуло-Бузького межиріччя - визначальний фактор щодо особливостей структурно-функціональної організації їхніх біотичних комплексів. Так, в умовах довготривалої (як мінімум, упродовж XVIII-XX ст.) гідрологічної нестабільності вказаних водотоків набували розвитку явища заболочування заплави. Руслові протоки в умовах накопичення алювію формували різко покраяну поверхню заплави, що стимулювало адаптивне виникнення дрібнолокальних різнотипових фітоугруповань, прямо залежних від рівня вологозабезпеченості середовища. Останній у долинах малих степових річок із мінімальним рівнем падіння русла (на межі 0,4-0,5 м/км) значною мірою залежить 
від рівня грунтових вод, які, зі свого боку, помітно різняться на різних ділянках водотоків із пересічними висотами від 120 до 10 м. Узагальнення фактичного матеріалу щодо глибин залягання грунтових вод на різних висотах (щодо рівня моря) ділянок степових водотоків дало змогу виявити певну закономірність, яка відображена графіками на рис. 1.
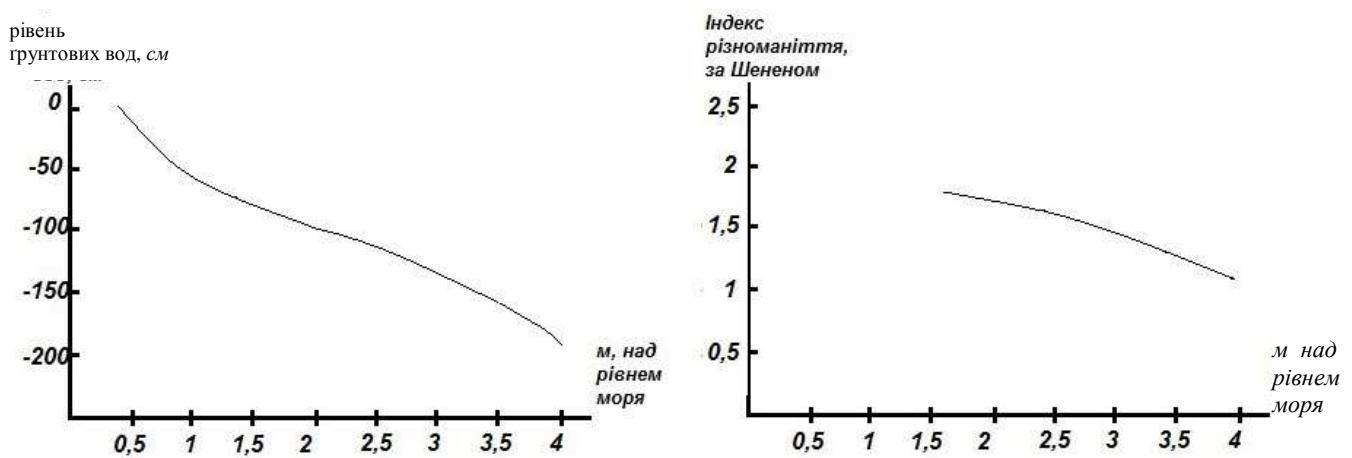

Рис. 1. Зв'язок видового фіторізноманіття луків Тилігулу (справжніх, остепнених, засолених) від рівня трунтових вод (нижня течія)

Отже, для малих річок підтверджено факт кореляційної залежності видового багатства плавневої рослинності з рівнем грунтових вод, що разом із поверхневим стоком прямо визначають стан зволоження заплави. Зрозуміло, що зі зменшенням зволоженості території будь-яких плавнів зменшується і їх фіторізноманіття, але саме на малих річках із сезонним режимом стоку виявлясться важливість фактора грунтових вод. Глибоке їх розміщення на окремих ділянках річок - головний чинник, який різко обмежує можливість збереження первинного типу плавневої рослинності в сухий сезон року. I навпаки, навіть довготривала відсутність поверхневого зволоження не спроможна суттєво обмежити видовий склад плавнів на ділянках із приповерхневим розміщенням грунтових вод.

Із-поміж вивчених і детально облікованих у процесі власних досліджень угруповань плавневої рослинності в період iї існування найбільше видове різноманіття за індексом Сімпсона - 2,86 (min 1,0, max $5,88)$ та Шенона - $1,94(\min 0,7, \max 2,1)$ установлено виключно для прибережно-водних екотопів, оскільки вони $є$ екотонними. У структурному відношенні угруповання цих ділянок представлено низкою видів, локальні популяції яких ростуть у значно відмінних умовах середовища. Так, рослинні комплекси прибережно-водних місцезростань уключають водні й болотні види, переважно із властивостями широкої екологічної амплітуди (очерет звичайний Phragmites australis, комиш озерний Scirpus lacustris, комиш Табернемонтана Scirpus tabernaemontani, бульбокомиш морський Bolboschoenus maritimus, лепешняк великий Glyceria maxima). Тож в умовах нестабільного гідрологічного режиму плавнів степових річок ці суто водні біотопи можуть мати ознаки і типових гідротопів, і лучних. Відповідно, їхня рослинність закономірно представлена видами, спроможними успішно виживати в різкозмінних гідрологічних умовах. Водночас установлені параметри індексу Бергера-Паркера для прибережно-водних місцезростань характеризуються високим ступенем домінантності $(\min 0,4, \max 1,0$, середній рівень 0,6$)$, що в реальності супроводжується вкрай нерівномірним розподілом рясності видів.

На відміну від «багатої» у видовому плані водно-прибережної рослинності, видове різноманіття сусідніх їм болотно-лучних екотопів різко обмежене. При цьому явище видового збіднення рослинності помітно виражене в просторі й має чітку спрямованість від русла в бік болотно-лучних екотопів. Останнє корелює з едифікаторами та їх габітусом, тож болотно-лучну рослинність переважно формують осокові, які мають високорослий габітус й утворюють щільні зарості. Закономірно, що асектаторами цих угруповань виступають тіньовитривалі види, серед яких представники світлолюбивих рослин трапляються лише поодинокими особинами. Загалом болотні фітоугруповання можуть поєднувати до 8-10 видів, але домінанти серед них займають до 90 \% проективного покриття. Це різко знижує видове багатство болотної рослинності, тож і показники індексу Шенона складають у середньому 1,02 (при min 0-1,7).

Умови екотопу справжніх луків характеризуються достатнім рівнем зволоження (тривалість весняного обводнення плавневих біотопів в окремі роки може сягати 5-10 днів, рівень грунтових вод - не глибше 50100 см), тож рослинність цих ділянок долини представлена гігрофітами, мезофітами, мезоксерофітами. 
Домінантами здебільшого виступають злакові. Травостій справжніх луків дещо розріджений (загальне проективне покриття - до 70-80 \%), що створює оптимальні умови для зростання багатьох видів. Тому, на відміну від болотних луків, ступінь домінантності фітоценозів справжніх лук дещо менший (індекс Бергера-Паркера, $\min --0,3, \max -0,9$, середнє - 0,58;), однак вони є більш флористично багатими угрупованнями (згідно з індексами Шенона ( $\min -0,34, \max -1,9$, середнє - 1,24).

Серед лучної рослинності плавнів річок досліджуваного межиріччя, останнім часом (за останні 20 років) значні площі стали займати лучно-галофітні угруповання. Вони характеризуються найбільш уніфікованим фіторізноманіттям (індекс Шенона $-0,92, \min -0, \max -1,62$ ) та найбільшою участю домінантів у фітоугрупованнях (індекс Бергера-Паркера - 0,63, $\min -0,3, \max -1$ ). Ці процеси спрощення видової структури лучних фітокомплексів корелюються зі ступенем засолення грунту. Чим більший уміст солей у грунті, тим менше видове багатство й найбільша ступінь домінантності фітоугруповання, скільки в тих умовах можуть виживати лише відповідно адаптовані галофіти, які часто утворюють моновидові зарості (содникові, полинові, скритницеві).

Із віддаленням від річища зменшується рівень зволоження заплави, який $є$ недостатнім для росту та розвитку типової плавневої рослинності. Ця особливість визначає формування відповідних умовам видових фітокомплексів й угруповань, утворених здебільшого мезоксерофітами та ксерофітами. Відповідно, видове багатство остепнених луків збіднене (індекс Шенона - 1,16 ( $\min -0,26, \max -1,6)$ (табл. 1). Ці фітокомплекси характерні для всіх плавневих біотопів степових річок досліджуваного межиріччя й виступають флористичною межею плавневих екосистем.

Аналітичне узагальнення індексів видового різноманіття різнотипових ділянок плавневої рослинності річкових долин Тилігуло-Бузького межиріччя відображено в табл. 1.

Таблиия 1

Індекси різноманіття різнотипових фітоугруповань плавнів степових річок ТилігулоБузького межиріччя

\begin{tabular}{|c|c|c|c|}
\hline Типи локальних рослинних угруповань & $\begin{array}{c}\text { Індекс } \\
\text { різноманіття } \\
\text { Сімпсона * }\end{array}$ & $\begin{array}{c}\text { Індекс } \\
\text { різноманіття } \\
\text { Шенона }\end{array}$ & $\begin{array}{c}\text { Індекс } \\
\text { домінантності } \\
\text { Бергера- } \\
\text { Паркера }\end{array}$ \\
\hline 1 & 2 & 3 & 4 \\
\hline \multicolumn{4}{|l|}{ Прибережно-водні } \\
\hline Очеретяно-комишево-рогозові & 4,55 & 1,37 & 0,4 \\
\hline Очеретяно-комишево-рогозові & 5,88 & 2,1 & 0,35 \\
\hline Очеретяно-комишево-рогозові & 4,67 & 1,97 & 0,4 \\
\hline Очеретяно-комишево-рогозові & 4,41 & 1,83 & 0,43 \\
\hline Рогозовошироколисті & 1 & 0 & 1 \\
\hline Рогозові & 1,7 & 0,59 & 0,73 \\
\hline Комишевотригранні & 1,55 & 0,73 & 0,8 \\
\hline Стрілолисті & 1 & 0 & 1 \\
\hline Їжачковоголівковопрямі & 1,04 & 0,12 & 0,98 \\
\hline \multicolumn{4}{|l|}{ Справжньолучні } \\
\hline Пирійникові & 1,25 & 0,34 & 0,9 \\
\hline Пирійниково-котячохвостовошандрові & 3,62 & 1,56 & 0,42 \\
\hline Китниково-пирійникові & 3,59 & 1,42 & 0,4 \\
\hline Китниково-осокові & 3,7 & 1,4 & 0,37 \\
\hline Кострицево-пирійникові & 5,55 & 2,09 & 0,3 \\
\hline Перстачево-осокові & 2,27 & 1,04 & 0,6 \\
\hline Перстачеві & 1,26 & 0,43 & 0,9 \\
\hline Кострицеві & 3,46 & 1,9 & 0,5 \\
\hline Кострицево-перстачевоповзучі & 1,75 & 0,74 & 0,73 \\
\hline Осокові & 3,48 & 1,74 & 0,5 \\
\hline Розхідникові & 1,47 & 0,61 & 0,81 \\
\hline Підмаренникові & 1,29 & 0,54 & 0,87 \\
\hline Козлятниково-кострицеві & 3,66 & 1,87 & 0,5 \\
\hline Козлятникові & 2,3 & 1,04 & 0,61 \\
\hline
\end{tabular}


РОЗДІЛ І. Ботаніка. 12, 2016

Закінчення таблииі 1

\begin{tabular}{|c|c|c|c|}
\hline 1 & 2 & 3 & 4 \\
\hline Комишево-морквяно-мітлицеві & 3,45 & 1,31 & 0,41 \\
\hline Тонконогові & 3,33 & 1,4 & 0,412 \\
\hline Мітлицевовелетенські & 3 & 1,61 & 0,56 \\
\hline \multicolumn{4}{|l|}{ Болотно-лучні } \\
\hline Очеретяні & 1 & 0 & 1 \\
\hline Осоковогострі & 1,96 & 1,1 & 0,7 \\
\hline Осоковопобережні & 1,95 & 1,1 & 0,7 \\
\hline Осоковопухирчасті & 2 & 0,68 & 0,57 \\
\hline Лепешняково-бульбокомишеві & 2,32 & 1,03 & 0,54 \\
\hline Ситниково-ситнягово-тонконогові & 3,87 & 1,54 & 0,35 \\
\hline Ситниково-ситнягові & 2,34 & 0,93 & 0,519 \\
\hline Бульбокомишево-щавлево-ситникові & 3,94 & 1,52 & 0,36 \\
\hline Півниковоболотні & 1,63 & 0,73 & 0,77 \\
\hline Комишеві & 5,2 & 1,7 & 0,25 \\
\hline Тонконоговоболотні & 1,93 & 0,99 & 0,7 \\
\hline Щучникові & 1,34 & 0,59 & 0,86 \\
\hline Рогозові & 2,83 & 1,4 & 0,57 \\
\hline \multicolumn{4}{|l|}{ Лучно-галофітні } \\
\hline Жерароситниково-Покісницеві & 4,2 & 1,31 & 0,32 \\
\hline Бульбокомишеві & 1,58 & 0,64 & 0,79 \\
\hline Бульбокомишево-комишеві & 1,96 & 0,86 & 0,66 \\
\hline Осокові & 3,84 & 1,53 & 0,44 \\
\hline Жерароситниково-мітлицеповзучі & 2 & 0,7 & 0,53 \\
\hline Жерароситниково-полинові & 4,34 & 1,63 & 0,36 \\
\hline Скритницеві & 1 & 0 & 1 \\
\hline Скритницево- мітлицеповзучі & 1,5 & 0,5 & 0,8 \\
\hline Полинові & 1 & 0 & 1 \\
\hline Полиново-бромусові & 1,6 & 0,56 & 0,75 \\
\hline Покісницевовелетенські & 3,7 & 1,5 & 0,44 \\
\hline Конюшиносуницево-солончаковоайстрові & 5,29 & 1,78 & 0,33 \\
\hline Кострицеві & 4,17 & 1,62 & 0,42 \\
\hline \multicolumn{4}{|c|}{ Справжньосолончакові сукулентно-трав'янисті } \\
\hline Содникові & 1 & 0 & 1 \\
\hline Солонцеві & 3 & 1,38 & 0,56 \\
\hline Полиново-содникові & 1,7 & 0,72 & 0,75 \\
\hline \multicolumn{4}{|l|}{ Остепнено-лучні } \\
\hline Шавлієво-гринделієві & 4,16 & 1,6 & 0,35 \\
\hline Шавлієво-кардарієві & 3,47 & 1,43 & 0,44 \\
\hline Кардарієві & 2,9 & 1,5 & 0,5 \\
\hline Шавлієво-гринделієві & 3,45 & 1,6 & 0,4 \\
\hline Бромусові & 2,15 & 1,05 & 0,16 \\
\hline Гринделієво-цикорієві & 2,94 & 1,25 & 0,5 \\
\hline Пижмові & 2,38 & 1,28 & 0,6 \\
\hline Подорожниковопіщано-аморфові & 2,1 & 0,95 & 0,67 \\
\hline Гринделієво-деревієві & 2 & 0,7 & 0,5 \\
\hline Татарнико-ячміневомишачі & 1,16 & 0,26 & 0,9 \\
\hline
\end{tabular}

* Примітка

\begin{tabular}{|l|c|c|c|}
\hline \multicolumn{1}{|c|}{ Індекс різноманіття } & $\begin{array}{c}\text { Низький рівень } \\
\text { багатства / } \\
\text { домінантності }\end{array}$ & $\begin{array}{c}\text { Середній рівень } \\
\text { багатства / } \\
\text { домінантності }\end{array}$ & $\begin{array}{c}\text { Високий рівень } \\
\text { багатства / } \\
\text { домінантності }\end{array}$ \\
\hline Індекс Сімпсона & $1-2$ & $2,1-3,5$ & $3,6-5,88$ \\
\hline Індекс Шенона & $0-1$ & $1-1,5$ & $1,6-2,1$ \\
\hline Індекс Бергера-Паркера & $0-0,3$ & $0,4-0,6$ & $0,7-1$ \\
\hline
\end{tabular}


Згідно $з$ даними табл. 1, серед різнотипових угруповань плавневої рослинності, найбільш «багатою» $€$ рослинність справжніх луків, однак найвищі кількісні показники видового різноманіття (індекс Шенона $-5,88$ ) характерні для очеретяно-комишево-рогозових рослинних угруповань прибережноводних екотопів.

Найбільше флористичне багатство прибережно-водної рослинності виявлене в плавневих ділянках первинного типу (Ковалівський масив Південного Бугу та передгирлова зона Тилігулу), які поєднують не менше ніж 15-20 видів. Дещо меншу видову насиченість (10-12) рослинності мають ділянки водно-прибережного типу річки Кодими, розміщені в зоні цілорічного обводнення. На відміну від останніх, угруповання водно-прибережної рослинності руслових ділянок Тилігулу, Березані, Чичиклії, Чертала й Бакшали зберегли лише 5-7 видів.

Серед фітоугруповань болотистих луків найбільш різноманітні (7-10 видів) рослинні угруповання плавнів Південного Бугу, Тилігулу та Кодими, хоча для плавневих зон усіх інших річок більш типові відносно «бідні» комплекси $32-4$ видів. Останні мають усі ознаки явного переважання моновидових масивів на основі очерету й різних видів комишу.

Згідно з отриманими даними щодо обліку видового складу рослинності справжніх луків установлено, що найбільше фітоценотичне різноманіття збережено на окремих ділянках нижньої течії Південного Бугу (на південь від устя Чичиклії) та середньої й нижньої ділянок течії Тилігулу. Незважаючи на цілорічний режим обводненості плавнів Кодими, у їі долині наявні ділянки справжніх луків, які також зберегли первинну структуру та високий рівень природного біорізноманіття. Фітоугруповання цих ділянок у долині Південного Бугу й Тилігулу відрізняє високий ступінь видової насиченості, який складає до 20 видів, тоді як для долини Кодими встановлено лише до 14 видів.

Флористично «бідні» угруповання справжньолучної рослинності з 3-5 видів $є$ майже фоновими для всіх степових річок, але найбільш звичайні в плавнях верхньої та середньої ділянок течії Бакшали й Чичиклії, для всієї долинної площі Сасику та Чертали. Головні причини такої «бідності» видового складу пов'язані з довготривалими негативними змінами гідрологічного режиму плавнів $\mathrm{i}$ постійно високим рівнем антропогенного навантаження. Вплив цих чинників призвів до втрати первинного складу рослинності та збереження лише евритопних видів, які майже не піддаються випасному вилученню, стійкі до посухи й спроможні успішно вегетувати на засолених грунтах.

Основна кількість локалітетів засолених луків припадає на плавні Чичиклії (солончакові, солончакуваті та солонцеві), Тилігулу й Кодими (солончакуваті та солонцеві). Щодо специфіки розміщення остепнених ділянок плавневих біотопів степових річок Тилігуло-Бузького межиріччя, то помітне значне поширення і явне тяжіння до притерасних частин заплави всіх водотоків досліджуваного регіону.

Висновки та перспективи подальшого дослідження. Серед угруповань плавневої рослинності досліджуваного межиріччя сучасного періоду найбільше видове різноманіття за індексом Сімпсона $(\min -1,0, \max -5,88$, середній показник $-2,86)$ та Шенона $(\min -0,7, \max -2,1$, середній показник $1,94)$ установлено виключно для прибережно-водних екотопів, оскільки ці ділянки є екотонними. Відповідно, останні зберегли первинну структуру й високий рівень фіторізноманіття плавнів степових річок (особливо Ковалівський плавневий масив Південного Бугу).

Узагальнення наявних матеріалів щодо особливостей видового складу фітоугруповань різною мірою засолених та остепнених ділянок плавнів степових річок Півдня України свідчить, що всі ценотичні форми рослинності останніх, порівняно зі справжніми й болотистими луками, мають украй звужене і явно уніфіковане фіторізноманіття (1-9 видів). Це вказує на спрощення видової структури фітоугруповань, що свідчить про порушення біоценозу та середовища взагалі. Більшою мірою це стосується плавневих біотопів середніх і малих річок межиріччя (Тилігулу, Чичиклії, Бакшали, Чертали, Березані й Сасика).

\section{Джерела та література}

1. Даниленко В. Л. Сукцесійні явища та темпи адаптаційних перетворень лиманних екосистем динамічно змінних геолого-кліматичних умовах Північно-Західного Причорномор'я / В. Л. Даниленко, І. О. Мазур // Науковий вісник МНУ імені В. О. Сухомлинського. Біологічні науки ; голов. ред. В. Д. Будак, І. В. Наконечний. - Миколаӥв : МНУ ім. В. О. Сухомлинського, 2014. - Вип. 6.3 (113). - С. $20-27$.

2. Даниленко В. Л. Сучасні проблеми екосистем Тилігульського лиману / В. Л. Даниленко, І. О. Мазур // Природа Західного Полісся та прилеглих територій : зб. наук. праць ; за заг. ред. Ф. В. Зузука. - Луцьк : Східноєвроп. нац. ун-т ім. Лесі Українки, 2015. - № 12. - С. 44-50.

3. Дубына Д. В. Плавни Причерноморья / Д. В. Дубына, Ю. Р. Шеляг-Сосонко. - Киев : Наук. думка, 1989. - 272 с. 
4. Мазур И. А. Антропогенная трансформация растительности плавневых биотопов / И. А. Мазур // Биосистема: от теории к практике : сб. тезисов ; материалы шк.-конф. молодых ученых на базе Ин-та фундаментальных проблем биологии РАН, 24-25 октября, г. Пущино. - Пущино, 2013. - С. 83-85.

5. Мазур I. О. Екологічна оцінка стану фітоценозів плавнів р. Південний Буг (на прикладі плавнів на околиці м. Вознесенська) / I. О. Мазур // Водні ресурси Миколаєва як потенціал розвитку міста. VIII Миколаївські міські екологічні читання «Збережемо для нащадків» (12-13 лист. 2015 р., м. Миколаїв). - Миколаїв, 2015. C. 51-53.

6. Мазур I. О. Еколого-фітоценотичні характеристики остепнілих луків плавневих біотопів р. Кодима / I. О. Мазур // Развиток науки в XXI ст., 1 ч. : матеріали XII міжнар. заочної наук.-практ. конф., Харків, 16 квіт. 2016 р. Дніпропетровськ : Наук.-інформ. центр «Знання», 2016. - С. 104-106.

7. Мазур I. О. Пасквальні зміни рослинності плавнів р. Чичиклія / І. О. Мазур // Прикладні аспекти техногенноекологічної безпеки : матеріали міжнар. наук.-практ. конф. (4 груд., 2015 р., м. Харків). - Харків, 2015. C. 229-230.

8. Мазур I. О. Фітоугруповання плавневих екосистем межиріччя Тилігулу - Південного Бугу / I. О. Мазур // Стан та перспективи розвитку заповідної справи та екологічного туризму в Україні : матеріали Всеукр. наук.-практ. конф. (21-22 берез. 2013 р.). - Миколаїв : Дизайн та Поліграфія, 2013. - С. 144-146.

9. Мазур І. О. Фітоценотична характеристика плавневих біотопів в сучасних еколого-гідрологічних умовах заплави Тилігулу (нижня течія) / I. О. Мазур // Развиток науки в XXI ст., 1 ч : матеріали XI міжнар. заочної наук.-практ. конф., Харків (14 берез. 2016 р.). - Дніпропетровськ : Наук.-інформ. центр «Знання», 2016. C. 34-37.

10. Мэгарран Э. А. Экологическое разнообразие и его измерение / Э. А. Мэгарран ; пер. с англ. Н. В. Матвеевой. М. : Мир, 1992. - $161 \mathrm{c.}$

11. Наконечний І. В. Еколого-гідрологічні та гідрохімічні чинники циклічних сукцесій водних екосистем Тилігульського лиману / І. В. Наконечний, В. Л. Даниленко // Агроекологічний журнал . - 2014. - № 4. - С. 16-22.

12. Уиттекер Р. Сообщества и экосистемы / Р. Уиттекер ; пер. с англ. Б. М. Миркина, Г. С. Розенберга. — М. : Прогресс, 1980. - 327 с.

13. Berger W. H. Diversity of Planktonic Foraminifera in Deep-Sea Sediments / W. H. Berger, F. L. Parker // Science. Vol. 168 (3937). - 1970. - P. 1345-1347.

14. Shannon, C. E. Warren Weaver. The mathematical theory of communication / C. E. Shannon. - Urbana : The University of Illinois Press, 1949. - 117 p.

15. Simpson E. H. Measurement of diversity / E. H. Simpson // Nature. - 1949. - Vol. 163. - P. 688.

16. Whittaker R. H. Evolution and Measurement of Species Diversity / R. H. Whittaker // Taxon, 1972. - Vol. 21, No. 2/3. P. 213-251

Мазур Ирина. Экологическая оценка фиторазнообразия плавневых биотопов степных рек междуречья Тилигул-Южного Буга. Проведена экологическая оценка фиторазнообразия плавневых битопов междуречья Тилигул - Южного Буга на основе аналитико-статистических методов, которая позволяет сделать прогностические оценки состояния и уровня деструкции биоценоза таких динамически и экологически уязвимых экокомплексов, как плавни. Данные исследования проводили с использованием мер разнообразия - информационно-статистических индексов флористического богатства (индекс разнообразия Шеннона (1949)) и доминантности / выравненности видовой структуры плавневых растительных сообществ (по индексам Симпсона (1949) и Бергера-Паркера (1970)). Аналитический анализ показал, что наибольшее разнообразие биотопов характерно для прибрежно-водной растительности плавневых биотопов. Флористически «бедными» являются ценозы остепненных и засоленных лугов плавней с неравномерным распределением обилия видов соответствующих сообществ или высокой степенью доминантности, что свидетельствует о нарушенном состоянии данных биоценозов.

Ключевые слова: экологическая оценка, фиторазнообразие, плавневые биотопы, степные реки, междуречье Тилигул-Южный Буг.

Mazur Iryna. Ecological Assessment of Phytodiversity of Marsh Biotopes of the Tylihul-Southern Buh Interfluve's Steppe Rivers. The publication presents the results of the ecological assessment of phytodiversity of marsh biotopes of the Tylihul-Southern Buh interfluve's steppe rivers. The applied analytical and statistical method made it possible to perform predictive evaluation of the destruction level of biocenosis of marshes as highly dynamic and ecologically vulnerable environmental complexes. The investigations were conducted with the application of the diversity indices, such as informational-statistical indices of floral wealth (the Shannon's Diversity Index (1949)) and richness/evenness indices of different species of marsh biotic communities (the Simpson's Diversity Index (1949)) and the Berger-Parker Index (1970). The performed analysis revealed that the reachest biodiversity is inherent in the riverine water vegetation of marsh biotops. Plant communities of steppificated and salt marsh meadows with uneven distribution of the corresponding groups of species or high richness level are poor in vegetation, which evidences about the destructed state of the biotic communities.

Key words: ecological assessment, phytodiversity, marsh biotopes, steppe rivers, the Tylihul-Southern Buh interfluve.

Стаття надійшла до редколегії 12.09.2016 р. 